\title{
A synthesis of the echinoderm fauna of the Maltese islands
}

\author{
Christine M. Tanti and Patrick J. Schembri* \\ Department of Biology, University of Malta, Msida MSD06, Malta. \\ *Corresponding author, e-mail: patrick.j.schembri@um.edu.mt
}

\begin{abstract}
A review of existing literature records of echinoderms from Malta and a study of a large collection of specimens was carried out between 2000 and 2004 so as to update and produce a validated checklist of echinoderms occurring in Maltese waters. Seventy different species of echinoderms are recorded, including a number of species for which only single records exist for the Maltese islands and five species that were not found in the present study. The Maltese echinoderm fauna includes $45 \%$ of the 153 recorded Mediterranean echinoderm species, and apart from two aliens, is typical of the central Mediterranean region.
\end{abstract}

\section{INTRODUCTION}

Although echinoderms are amongst the most conspicuous marine organisms in the Maltese islands, knowledge of these animals is quite limited. Apart from a handful of papers recording species (Despott, 1930; Micallef \& Evans, 1968; Schembri, 1978; Zavodnik, 1981; ZammitMaempel, 1986), most other records are found in unpublished reports of ecological surveys of marine sites earmarked for development. To redress this, we examined a large collection of specimens from Maltese waters amassed by ourselves and by other workers. This collection included specimens resulting from research and student projects carried out at the University of Malta, discards and by-catch from fishers, material from ecological surveys of marine development sites, and specimens from private collections. Additionally, we reviewed and evaluated literature records, and where in doubt about the validity of some of these, we endeavoured to trace and examine the original material on which the published record was based to verify the identification. Altogether, between 2000 and 2004, we were able to examine and identify 65 echinoderm species and on the basis of this, we present here a comprehensive and validated checklist of echinoderms that occur in Maltese waters.

\section{RESULTS}

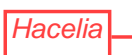

A total of 65 different species of echinoderms were identified in this study. These comprised two crinoids, 16 asteroids, 20 echinoids, 15 ophiuroids and 12 holothurians (Table 1). Another five species (Chaetaster longipes, Asterina pancerii, Echinus melo, Echinocardium mediterraneum and Brissopsis lyrifera) have been reported in the literature but were not examined by us. As presently known, the Maltese echinoderm fauna comprises $45 \%$ of the overall Mediterranean fauna which at present consists of 153 species (Rinelli, 1998; Hansson, 1999).

Twenty species of echinoderms are recorded here for the first time for Maltese waters. These consist of one asteroid (Astropecten jonstoni), one crinoid (Leptometra phalangium), three echinoids (Eucidaris tribuloides, Echinocardium cordatum and Echinocardium flavescens), eight holothurians (Holothuria helleri, Holothuria mammata, Holothuria sanctori, Holothuria
Table 1. Checklist of the echinoderms of the Maltese islands.

Taxa

L P

Class ASTEROIDEA

Anseropoda placenta (Pennant, 1777)

Asterina gibbosa (Pennant, 1777)

Asterina pancerii (Gasco, 1870) [e]

Astropecten aranciacus (Linnaeus, 1758)

Astropecten bispinosus (Otto, 1823) [e]

Astropecten irregularis pentacanthus (Delle Chiaje, 1825) [e]

Astropecten jonstoni (Delle Chiaje, 1825) [e]

Astropecten platyacanthus (Philippi, 1837) [e]

Astropecten spinulosus (Philippi, 1837) [e]

Chaetaster longipes (Retzius, 1805)

Coscinasterias tenuispina (Lamarck, 1816)

Echinaster sepositus (Retzius, 1783)

Hazelia attenuata Gray, 1840

quidia ciliaris (Philippi, 1837)

Marthasterias glacialis (Linneaus, 1758)

Ophidiaster ophidianus (Lamarck, 1816)

Peltaster placenta (Müller \& Trochel, 1842)

Tethyaster subinermis (Philippi, 1837)

\section{Class EGHINOIDEA}

Arbacia lixula (Linnaeus, 1758)

Arbaciella elegans Mortensen, 1910

Brissopsis lyrifera (Forbes, 1841)

Brissus unicolor (Leske, 1778)

Centrostephanus longispinus (Philippi, 1845)

Cidaris cidaris (Linnaeus, 1758)

Echinocardium cordatum (Pennant, 1777)

Echinocardium flavescens (O.F. Müller, 1776)

Echinocardium mediterraneum (Forbes, 1844)

Echinocyamus pusillus (O.F. Müller, 1776)

Echinus acutus Lamarck, 1816

Echinus melo (Lamarck, 1816)

Eucidaris tribuloides (Lamarck)

Genocidaris maculata A. Agassiz, 1869

Neolampas rostellata A. Agassiz, 1869

Paracentrotus lividus (Lamarck, 1816)

Plagiobrissus costai (Gasco, 1876)

Prionocidaris baculosa (Lamarck, 1816)

Psammechinus microtuberculatus (Blainville, 1825)

Schizaster canaliferus (Lamarck, 1816)

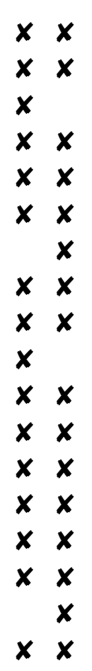

$x \times$

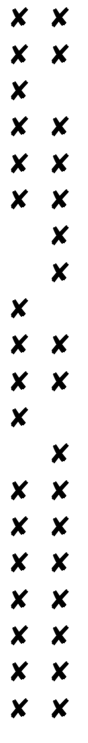

(continued) 
Table 1. (Continued).

Taxa

L P

\section{Glass EGHINOIDEA (continued)}

Spatangus purpureus (O.F. Müller, 1776)

Sphaerechinus granularis (Lamarck, 1816)

Stylocidaris affinis (Philippi, 1845)

\section{Class GRINOIDEA}

Antedon mediterranea (Lamarck, 1816) [e]

Leptometra phalangium (J. Müller, 1841) [e]

\section{Glass HOLOTHUROIDEA}

Holothuria forskali Delle Chiaje, 1823

Holothuria helleri Marenzeller, 1878 [e]

Holothuria impatiens (Forsskål, 1775) [e]

Holothuria mammata Grube, 1840 [e]

Holothuria polii Delle Chiaje, 1823

Holothuria sanctori Delle Chiaje, 1823

Holothuria tubulosa Gmelin, 1788

Leptosynapta minuta (Becher, 1906)

Stichopus regalis (Cuvier, 1817)

Trachythyone elongata (Düben-Koren, 1844)

Trachythyone tergestina (M. Sars, 1857) [e]

Trochodota venusta (Semon, 1887) [e]

\section{Glass OPHIUROIDEA}

Amphipholis squamata (Delle Chiaje, 1828)

Amphiura brachiata (Montagu, 1804)

Amphiura chiajei Forbes, 1843

Amphiura filiformis (O.F. Müller, 1776)

Astrospartus mediterraneus (Risso, 1826)

Ophiacantha setosa (Retzius, 1805)

Ophiocomina nigra (Abildgaard in O.F. Müller, 1789)

Ophioderma longicaudum (Retzius, 1805)

Ophiomyxa pentagona (Lamarck, 1816)

Ophiopsila annulosa (M. Sars, 1857)

Ophiopsila aranea Forbes, 1843

Ophiothrix fragilis (Abildgaard, 1789)

Ophiura albida Forbes, 1839

Ophiura grubei Heller, 1863

Ophiura ophiura (Linnaeus, 1758)

L, literature; P, present study; e, Mediterranean endemics.

impatiens, Stichopus regalis, Leptosynapta minuta, Trachythyone elongata, Trachythyone tergestina), and seven ophiuroids (Amphiura brachiata, Ophiocantha setosa, Ophiocomina nigra, Ophiopsila annulosa, Ophiopsila aranea, Ophiura albida and Ophiura ophiura). The record of Eucidaris tribuloides is, as far as we are aware, also the first for the Mediterranean.

\section{DISGUSSION}

Of the 43 (excluding doubtful records) echinoderm species endemic to the Mediterranean (Tortonese, 1979; Rinelli, 1998; Hansson, 1999), 13 (30\%) occur in Maltese waters (Table 1).

Bathyal species are generally lacking from the Maltese list since bathyal depths are not found in Maltese waters. One exception is the asteroid Brisingella coronata (O. Sars, 1871), which although essentially a bathyal species, in the central Mediterranean seems to occur at much shallower depths; we have personally collected specimens of this species from $70 \mathrm{~m}$ from Medina Bank and from $100 \mathrm{~m}$ off the island of Lampedusa (Tanti, 2003). Circalittoral species, particularly infaunal forms, were also generally poorly represented in our samples; however, in this case this is likely due to the dearth of studies on the aphytal zone within Maltese waters, especially on muddy substrata.

Five species recorded in the literature were not examined during this study. The asteroid Chaetaster longipes is a large conspicuous lower circalittoral/upper bathyal species (Zibrowius, 1992) that was only recorded by Micallef \& Evans (1968) without any indication of provenance, habitat or collection data. Asterina pancerii is another asteroid only recorded by Micallef \& Evans (1968), again without any information. This species is very similar to the common Asterina gibbosa from which it differs primarily in the number of spines on the dental plates (Tortonese, 1965). We examined in detail 185 individuals of Asterina from rocky and pebbly bottoms and from sea grass meadows; while a few individuals had some morphometric and morphological characteristics that place them as Asterina pancerii, and many had intermediate characteristics between Asterina pancerii and Asterina gibbosa, however, none had the dental plate characteristics diagnostic of Asterina pancerii. The morphological differences between Asterina gibbosa and Asterina pancerii may not justify separation of these two forms as species and Asterina pancerii is considered by some as a variety of Asterina gibbosa (Ameziane, 1999).

Echinus melo was recorded by Schembri (1978) on the basis of one dead test brought ashore in fishers' nets. The actual provenance of this single specimen is unknown and we have not seen any live or dead specimens of this species from Maltese waters. Echinocardium mediterraneum is known from Malta on the basis of three tests recovered from the shore or from very shallow water close to shore and from two live specimens dug up close to shore (ZammitMaempel, 1986). Brissopsis lyrifera was reported for the Maltese fauna by Zavodnik (1981). This species is very similar to Brissus unicolor from which it differs by the presence of a deep canal at the anterior aboral surface (Tortonese, 1979); none of the more than 60 specimens examined by us had such a canal. Therefore, excepting Echinocardium mediterraneum, for the present we retain the other four species not found by us as unconfirmed for the Maltese islands.

The cidariid Prionocidaris baculosa, a common Indian Ocean species, was recorded during cleaning of the ballast water tanks of a ship at the Malta dockyard (Schembri, 1978); no population of this species has established itself in Maltese waters.

During the present study, a second alien cidariid was recorded: Eucidaris tribuloides a species widely distributed in the Atlantic Ocean on different substrata, including sedimentary and rocky bottoms, and at depths ranging from very shallow $(1 \mathrm{~m})$ to relatively deep water $(450 \mathrm{~m})$ (McPherson, 1968). Two populations of this species were found, one each in the two principal harbours of Malta; in the Grand Harbour a population was found in the inner part of a sheltered creek (Kalkara Creek) on mud at depths of 3-10 m, while in Marsamxett Harbour, a second population was found in Sliema Creek on a bottom of muddy sand at a depth of 3-7 $\mathrm{m}$. Although the bottom was fine sediment in both localities, individuals 
occurred on debris or some other hard substratum. In both localities one or two aggregates of 5-10 adult individuals each were noted, however, total population size was very difficult to assess due to the very limited visibility. The absence of other records of this species from the Mediterranean suggests that it was accidentally introduced to the Maltese islands by shipping, possibly through ballast water.

We thank various persons who generously made their echinoderm material available for this study, in particular DrJoseph A. Borg, Mark Dimech, Edwin Lanfranco, Constantine Mifsud, Rebecca Page, the Malta Centre for Fisheries Sciences, and the Maltese BIOMAERL and AVICENNE teams (both research projects funded by the European Union). We are grateful to Konrad Pirotta for collecting specimens of Eucidaris tribuloides for us and to Dr Andrew B. Smith of the Natural History Museum, London, for their identification and for other taxonomic advice. The helpful comments of two referees on an earlier draft of this paper are gratefully acknowledged. This work was supported in part by research grants from the University of Malta for which we are grateful.

\section{REFERENCES}

Ameziane, N., 1999. Asterina pancerii (Gasco, 1870). http:// www.mnhn.fr/mnhn/bimm/protection/fr/Especes/Fiches/ Asterinapancerii.html. Date accessed 10 March, 2003.

Despott, G., 1930. Echinological notes. The Bulletin of the Museum [of Natural History], 1(2), 4-5. Valletta, Malta: Empire Press.

Hansson, H.G., 1999. European Echinodermata Check-list: a draft for the European Register of Marine Species (part of 'Species 2000') compiled at TMBL (Tjärnö Marine Biological Laboratory) by Hans G. Hansson; January 1999 (revised 2 March 1999); http://www.tmbl.gu.se/libdb/taxon/ neat_pdf/EurEchin.pdf Most recently accessed 16 January, 2005.
McPherson, B.F., 1968. Contributions to the biology of the sea urchin Eucidaris tribuloides (Lamarck). Bulletin of Marine Science, 18, 400-443.

Micallef, H. \& Evans, F. 1968. The marine fauna of Malta. [Echinodermata pp.21-24]. Msida, Malta: The Royal University of Malta, Biology Department.

Rinelli, P., 1998. A synthesis of the echinoderm fauna of the Tyrrhenian Sea. Rapport du Congrès de la Commission Internationale pour l'Exploration Scientifique de la Mer Méditerranée, 35, 484-485.

Schembri, P.J., 1978. Recent echinoids (Echinodermata: Echinoidea) from the Maltese Islands and surrounding waters. Animalia, 5, 123-132.

Tanti, C., 2003. A taxonomic study of echinoderms of the Maltese Islands and surrounding waters. MSc thesis, University of Malta, Msida, Malta.

Tortonese, E., 1965. Echinodermata. [Fauna d'Italia 6] Bologna, Italy: Calderini.

Tortonese, E., 1979. Review of the present status of knowledge of the Mediterranean echinoderms. In Proceedings of the European colloquium on Echinoderms, Brussels, 3-8 September, 1979, pp. 141149. Amsterdam: A.A. Balkema.

Zammit-Maempel, G., 1986. Observations on Echinocardium (Echinodermata: Echinoidea) from Maltese waters (Central Mediterranean). Atti della Societa Toscana di Scienze Naturali Memorie, Serie B, 93, 225-240.

Zavodnik, D., 1981. Report on Echinoderms from Malta. Rapport du Congrès de la Commission Internationale pour l'Exploration Scientifique de la Mer Méditerranée, 27, 225-226.

Zibrowius, H., 1992. Chaetaster longipes (Echinodermata, Asteroidea): distribution in the Mediterranean and Atlantic. Mesogée, 51, 7- 81 .

Submitted 17 January 2005. Accepted 9 November 2005. 